\title{
Teaching science and technology PhD students in entrepreneurship-potential learning opportunities and outcomes
}

\author{
Magnus Klofsten ${ }^{1}\left(\mathbb{D} \cdot\right.$ Dylan Jones-Evans $^{2}$ (D) $\cdot$ Luciana Pereira $^{3}$ (D)
}

Published online: 4 April 2020

(C) The Author(s) 2020

\begin{abstract}
Whilst doctoral students comprise a large group of researchers at a university and will potentially play important roles in the utilization and transfer of research results, prior research studies have paid little attention to the effect of entrepreneurship education on $\mathrm{PhD}$ students with a science and technology orientation. This paper seeks to address this gap in knowledge and examines four key elements in the design and evolution of good practice in entrepreneurship education for this group of students: (1) learning tools, (2) inspiration, (3) interdisciplinarity, and (4) boundary spanning networks. The paper illustrates the importance of identifying the balance between theory and practice that will attract students from across the spectrum of science and technology fields. It also shows that a hands-on experimental methodology is an effective pedagogical strategy that uses learning by doing as an essential tool in problem solving.
\end{abstract}

Keywords $\mathrm{PhD}$ entrepreneurship education · Learning tools · Inspiration · Interdisciplinarity $\cdot$ Boundary spanning networks

JEL Classification L26

Magnus Klofsten

magnus.klofsten@liu.se

Dylan Jones-Evans

dylan.jones-evans@southwales.ac.uk

Luciana Pereira

luciana.pereira@ufabc.edu.br

1 Helix Competence Centre and PIE, Department of Management and Engineering, Linköping University, Linköping, Sweden

2 South Wales Business School, University of South Wales, Treforest, Wales, UK

3 Graduate Program in Engineering and Innovation Management, Federal University of ABC, Santo André, Brazil 


\section{Introduction}

Various authors have suggested that the educational focus in undergraduate and postgraduate education has shifted intensity from a specialist orientation toward one that focuses on the development of general competences and various types of skills. As a result, university education has changed from a system focused on the élite to one for the masses with the concomitant result of a significant growth in student numbers at both undergraduate and postgraduate levels (Akerlind and McAlpine 2017; Shattock 2000; Neubauer et al. 2017; Sauermann and Roach 2016). At the same time, universities have actively been playing a larger role in regional and national economic and social development (Gibb and Hannon 2006; Youtie and Shapira 2008; Svensson et al. 2012). This includes the role universities play in the formation of human capital through education and research that has led to the emergence of a numerous initiatives designed to promote entrepreneurial activities within academic institutions such as entrepreneurship programmes, incubator facilities, and projects that link the university with regional businesses (Klofsten and Jones-Evans 2000; Hayter and Link 2015; Grimaldi et al. 2011). Increasingly, universities are introducing entrepreneurship modules into their undergraduate and graduate curricula with the mission to stimulate entrepreneurial thinking and support the next generation of entrepreneurs (Fayolle et al. 2006) although there seems to be little evidence of any strong links between entrepreneurship education and the research, transfer, and utilization of technology (Kingon et al. 2002).

Until recently, the focus on teaching on undergraduate education in entrepreneurship has been primarily concerned with various educational and content issues (Honig 2004). As a result, very few studies have paid attention to entrepreneurship teaching at the PhD level, especially in relation to students with a science and technology orientation. Consequently, entrepreneurship education for doctoral students remains a fairly unexplored topic although doctoral students comprise one of the larger groups of researchers at a university, play an important role in the creation of knowledge that utilizes research results, and are likely to become the future senior researchers whose intentions and actions will strongly affect how scientific output is developed and disseminated within higher education institutions (Thune 2009; Boh et al. 2016; Guerrero et al. 2016).

Therefore, effective models of entrepreneurship education for science and technology doctoral students might be an essential component in the mission of universities to become more entrepreneurial (Bienkowska and Klofsten 2012) and can cover a wide range of situations, aims, methods, and teaching approaches that do not focus exclusively on the immediate creation of new businesses. Indeed, processes that promote enterprising attitudes and skills which involve the development of personal characteristics that are useful to their roles as researchers or teachers are as critical as those which are focused on new venture creation (Huyghe and Knockaert 2015). In addition, the current oversupply of $\mathrm{PhD}$ graduates means that an entrepreneurial skill-set can be an asset when seeking employment in related or new fields both inside and outside of academia (Brush et al. 2003). Subsequently, this paper examines a case of good practice in enterprise education for doctoral researchers namely the "Entrepreneurship in Theory and Practice" programme (ETP) at Linköping University, Sweden. The course develops entrepreneurial skills in science and technology students at the PhD level, a process which is characterized by taking advantage of learning tools, increased inspiration of participants, interdisciplinary idea development, and boundary spanning activities 
among the students and their peers, all of which will be described in detail within this paper. ETP has been taught annually since 2006 and a total of 188 doctoral students from a dozen science and technology disciplines have participated.

\section{Aim and scope}

The aim of this paper is to examine key elements in the design and evolution of good practice in entrepreneurship education for doctoral students in science and technology as well as addressing policy recommendations for postgraduate entrepreneurship education. When comparing doctoral programs at the international level, it is important to consider the differences between systems with regard to the duration and focus of $\mathrm{PhD}$ education, the theoretical courses that are compulsory, and the different programmes that must be taken during the actual writing of the thesis (Swedish Agency for Growth Policy Analysis 2015). In the Swedish system, a doctoral degree comprises 4 years of full-time study, including a requirement to undertake courses to the value of 60-90 European Credit Transfer and Accumulation System (ECTS). Many courses are compulsory and reflect the discipline studied by the doctoral students but there is also flexibility for electives in many programmes include courses in entrepreneurship. Internationally, there are many different doctoral courses in entrepreneurship, and ETP shouldn't be seen as unique but as this paper will demonstrate, an exemplar of good practice for the development of similar postgraduate entrepreneurship courses.

\subsection{ETP as good practice}

Whilst the ETP course can be viewed as part of an emerging and well-developed support structure for developing entrepreneurship amongst students and staff at the university since the 1980s (Etzkowitz and Klofsten 2005), there had been criticism of the low integration of entrepreneurship into doctoral education by the Swedish Council for Higher Education. This resulted in the dean of the Faculty of Science and Engineering approaching the chair in entrepreneurship and setting aside resources for starting up a new $\mathrm{PhD}$ course. That led to the start of the first ETP which was launched in 2006 and since then twelve courses have been completed.

Since it began, ETP has attracted PhD students from a broad spectrum of research fields in science and technology including management, computer and information sciences, engineering, and medical/health sciences. As such, each cohort comprises of a fairly heterogeneous group regarding study curricula, organization, and research team affiliation. The course is non-compulsory and many participants are students who wouldn't normally consider undertaking a taught postgraduate programme outside of their research field. However, the motivations for participation are linked to individual career goals, research group needs and, not least, developing a positive track record in the local academic community. Furthermore, the $\mathrm{PhD}$ supervisory group plays a critical role and approval from them is usually a prerequisite for participation.

Another reason for viewing ETP as a good practice is the philosophy at the heart of the design of the programme which allows the participants define and develop their own ideas linked to their research. This includes personal coaching as well as workshops that address various entrepreneurial practices and theories adapted for students with no previous 
experience in business and management. This combination of ideation, coaching and networking has resulted in different side effects that were not the pre-determined aims of ETP i.e. the ideas developed by the PhD students on the ETP have led to the creation of over 20 start-ups with three of them having attracted 15 million euro in venture capital and one firm being recently acquired by Microsoft for 90 million euro.

\subsection{The key elements of ETP}

Approaches vary in studying the key elements of good practice within different programmes. For example, Szulanski (1996) focused on the transfer of good practice within larger organization whereas Klofsten et al. (2010) defined a set of success factors for the transfer of good practice between organizations. However, most studies on good practice are more illustrative where one or more cases are compared in order to demonstrate certain characteristics that researchers and policymakers can learn from. This study is closer to the latter type in that it explores a perceived knowledge gap between current teaching practices in entrepreneurship and the actual learning needs of doctoral students in science and technology. As will be described below, previous research suggests there are four key elements which are critical in understanding entrepreneurship programmes within higher education namely (1) the learning tools utilised within each programme, (2) the inspiration for entrepreneurial intentions by participants in their future career, (3) the interdisciplinary effects of collaboration with other programme participants, and (4) boundary spanning networks across different cultural and organisational settings (Fig. 1).

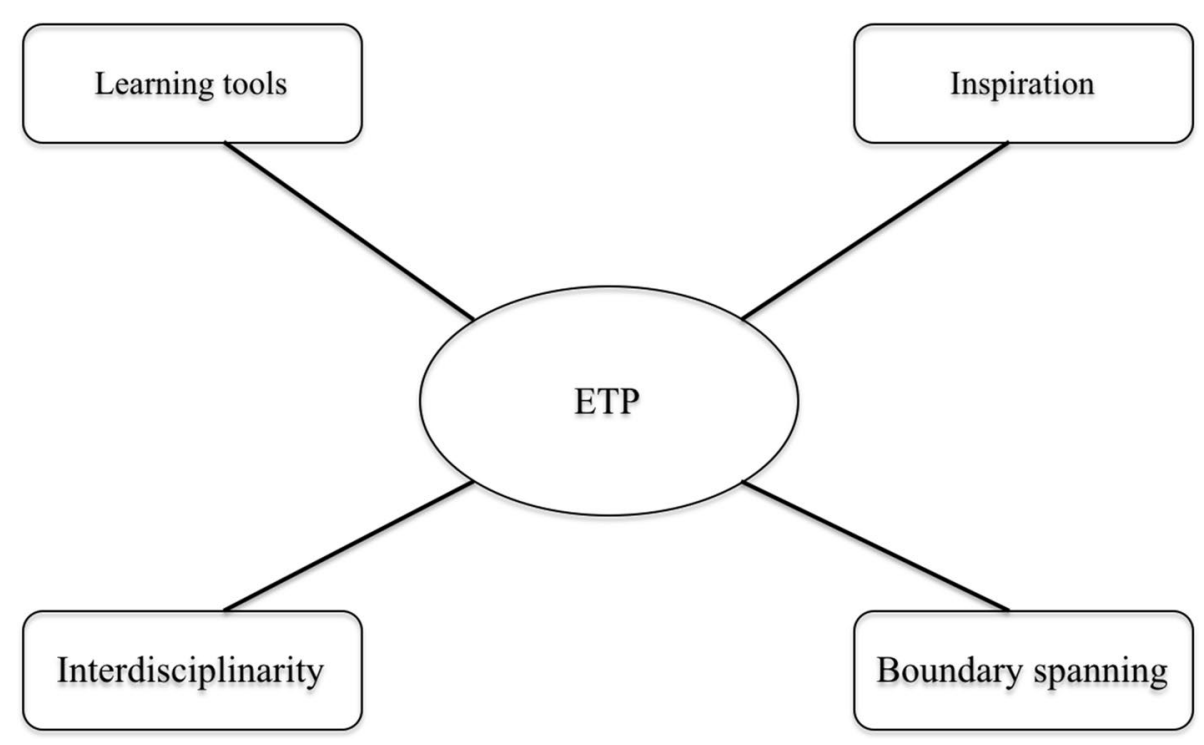

Fig. 1 Key elements in ETP 


\subsection{Learning tools within entrepreneurship education programmes}

Learning tools in ETP refer to structures and models that aim to assess and facilitate processes of generating and shaping venture ideas as well as what is takes to set up a competitive entrepreneurial team. Such tools could be NABC-models (Norrman et al. 2014), Business Model Canvas (Osterwarder 2010), the Business Platform Model (Davidsson and Klofsten 2003), business plans (Honig and Karlsson 2004), smartphone apps (Lackéus et al. 2015) and multi-founder models (Powell and Baker 2017). The presence of passion, energy and an idea is not enough to convince potential customers and other resource providers of the excellence of the venture. In order to take the next step, the entrepreneur needs to learn what the useful tools are in order to organise, clarify and increase the credibility of the new venture to overcome its liability of newness (Singh et al. 1986; Politis 2005). Furthermore, the challenge is to use the right tools to capture the holistic feature of the early development process encompassing venture characteristics, the entrepreneurial team as well as the surrounding environment (Davidsson and Klofsten 2003). To increase learning, it is beneficial to translate entrepreneurship into practice by offering coaching by real entrepreneurs, organizing meetings with potential customers or by real business case analysis. Such an approach that is based on practice stimulates learning and is particularly important when it comes to teaching those science and technology students who may not have taken any preparatory courses in financing, organisation and business administration, all of which are crucial elements in the entrepreneurship process (Bonnet et al. 2006).

\subsection{Inspiration for entrepreneurial intentions}

Inspired individuals are the key in the entrepreneurship process and are a prerequisite for creativity, learning, new ways of thinking and the empowerment during entrepreneurial activities (Souitaris et al. 2007; Al-Dajani and Marlow 2013). Earlier research has shown that inspiration (or motivation) is a crucial factor behind the success of businesses and why new ventures grow and develop (Baum and Locke 2004). In this respect, ETP acts as a trigger that evokes inspiration to not only motivate participants into an entrepreneurial career but can also be a catalyst for others in the close environment of the ETP to become future entrepreneurs (Liñán and Fayolle 2015). Inspired ETP alumni can also encourage other doctoral students to join the course thus becoming important recruitment mediators for future ETP courses. Many ETP participants do not see themselves as entrepreneurs and may not even have thought of being an entrepreneur before entering the course. Thus, it is important that the participants meet entrepreneurial role models which is facilitated by using workshop leaders with a successful entrepreneurial career or offering certain course modules that address the range of opportunities that doctoral students could have to become future entrepreneurs regardless of whether they remain at the university or work outside the academy.

\subsection{Interdisciplinarity effects}

The basic philosophy of this course is that teaching entrepreneurship to a varied cohort of scholars from different science and technology disciplines can positively stimulate individual and group learning as well as new business development (Kickul et al. 2011). In discussing a problem with another individual whose studies and experiences differ from one's own, one is encouraged to view the problem from a new angle and consider the possibility 
of new methods as its solution. This is further enhanced when this situation is expanded into a learning group where the backgrounds of each individual are grounded in different academic disciplines, each with its own particular uniqueness, methodological approach and concepts. The potential for discovering a new way of managing a problem and developing a viable solution by combining aspects of previously unrelated knowledge becomes synergistic especially if compared with a similar situation when researchers from the same discipline work in isolation (Lyons and Zhang 2018). Research has shown that successful technological projects are not only dependent on management by individuals with welldefined roles but they also need an environment where different scientific disciplines can meet, be combined, and develop into something new (Wateridge 1995). A similar philosophy is behind ETP where a learning platform is built to incorporate the variety of different disciplinary lenses available to enhance the work of an entrepreneurial team.

\subsection{Boundary spanning networks}

Boundary spanning has over the years attracted certain interest and organisations have launched initiatives aimed at accelerating and enhancing inter-organisational sharing and utilisation of research results (Youtie and Shapira 2008). As noted, participants on the ETP emanate from different disciplinary backgrounds and research environments and boundary spanning networks are established between individuals that probably wouldn't have happened without taking the course. The boundary spanning that takes place within ETP is multifaceted and comprises several dimensions related to ethnicity, culture, and interorganizational affiliation, as well as the participant's personal relationships with the doctoral supervisor(s) and other colleagues in the local research environment. Thus, in the idea development process which the teams establish in the beginning of the course, there might exist certain opportunities to take advantage of the differences among participants with various backgrounds, organizational and research disciplinary affiliation. As a result, the benefits of boundary spanning extend beyond the interdisciplinarity skills of the team members and can allow the group to independently explore outside resources developed by different individuals (Zucker and Darby 1996). In fact, the boundary spanning individual will use existing or build new relationships, collaborations, and networks, that reach across institutional homes and sometimes beyond the borders of the university itself (c.f. Dubini and Aldrich 1991).

\section{Method and data}

This paper examined ETP - $\mathrm{a} \mathrm{PhD}$ entrepreneurship course for science and technology students as the object of analysis. Data on the programme was collected from the course participants, following the guidelines for representational examination and constant comparison techniques (Glaser and Strauss 1967). Three sources of qualitative data were collected over the 10 years of the course namely:

- Course evaluations At the end of each course, participants were required to fill out an compulsory evaluation form where each section of the course could be graded, but which also asked the participants to suggest improvements, to indicate how the course helped their PhD career, reasons for selecting the course and whether the course had 
met their expectations. There were 188 evaluations available for analysis and these had been fact-checked with participants annually by the course leader to ensure accuracy of the data submitted.

- Coaching reports In the course, each working group meets twice with a coach and writes up notes on the meeting afterward. The reports describe the idea that the groups are developing, what the idea should result in, the work and commitment of the group, and progress between the coaching meetings. An open question queries other issues such as group dynamics, entrepreneurial driving forces, and networking issues. A total of 180 coaching reports assessed by the same single coach were available for analysis.

- Presentations during the examinations Ninety oral presentations were made over the years. Each group had 45 min (including discussions) to present their project and notes from these presentations were also available. All presentations were also submitted in written reports. These were judged by the same two individuals (the course leader and the coach).

Over the ten-year period of the programme, the same individual organized the data collected annually from the above sources into a single cohesive case study database (Yin 2011). To ensure that the data collected was correctly transcribed, notes from the course evaluations, coaching meetings and the final presentations were used to crosscheck the original data sources for accuracy. Employing the coding methods described by Corley and Gioia (2004), initial concepts were identified and grouped under the four key elements which describe entrepreneurial education programmes (as described earlier) namely: (1) acquired skills from the learning tools within the programme; (2) inspiration for entrepreneurial intentions of the doctoral students in their future career; (3) the interdisciplinary effects of collaborating with other doctoral students in other fields of research; and (4) the boundary spanning effects of working with $\mathrm{PhD}$ students and staff from other departments at the university.

Utilising these themes emerging from the three empirical sources described above, a retrospective evaluation was then conducted with the previous programme participants which comprised of a series of open questions (apart from basic questions on dates of participation, gender, nationality, location and disciplinary field for the doctoral thesis) to determine the content foci for further detailed analysis of the programme (Strauss and Corbin 1998). All PhD students who had participated in ETP between 2006 and 2016 were sent the questionnaire and $82(51 \%)$ responded. Relationships were then analysed between these four categories in order to place them into higher order themes and these themes were then arranged under the overarching dimensions of the emergent framework.

The first results from this analysis were presented at the Academy of Management Meeting in 2016 where a key strength of the study identified was the dedicated time that the students had allotted to fill out the course evaluation and to reflect over their responses. However, one limitation discussed was the inherent subjectivity of the reports and notes that formed the three sources of qualitative data, although the coaches, course leaders, and others who were present at the time discussed the validity and accuracy of the data. Another potential limitation was that the students attended the course at different time points, and there was a risk that students from the earlier programmes would not accurately recall the actual content and its contribution. Finally, whilst third party assessors could have been utilised but the cost would have been prohibitive given this was an annual academic programme rather than a specific research study and there 
would have been a loss of consistency if the same assessors had not been used (as was the case with the course leader and coach).

\section{Results}

A number of key findings emerged from the analysis of the retrospective evaluation with the previous ETP programme participants.

\subsection{Inflow of PhD students}

Previous experience yielded two valuable lessons that improved the attractiveness of ETP and helped create a good in-flow of participants. One came from a successful entrepreneurship program that had been conducted since the beginning of the 1990s and which had generated a large number of technology-based firms (Klofsten and Lundmark 2016); and the other was the result of 10 years of prior experience with entrepreneurship courses at the undergraduate level for science and technology students (Norrman et al. 2014). These programmes and courses had shown that the course should be practically oriented in order to be suitable for a wide target group in which the majority of participants (including $\mathrm{PhD}$ students in science and technology) had no theoretical background in business, finance, management, or organization. The ETP was not meant to be a compulsory module for doctoral students and it was assumed that it should be able to sell itself on its own missions and merits i.e. the content had to be attractive enough in order to interest students from an academic context where entrepreneurship is usually not on the agenda. It was also important to communicate to participants that entrepreneurship is not limited only to new venture creation since there are many ways that researchers can be entrepreneurial as they strive to realize new possibilities in their roles as academics. These arguments became important factors in making the course attractive not only for the students themselves but also for their supervisors who needed to give their approval for their students to enrol in the course. Good relations with the various research environments of potential participants was considered an important factor in successful recruitment.

With a gender distribution of 70/30 male/female, the $188 \mathrm{PhD}$ students who participated in the twelve ETP courses have different science and technology disciplines (Table 1) with

Table 1 Research disciplines and number of participants in ETP between 2006 and 2019

\begin{tabular}{lc}
\hline Research discipline & $\begin{array}{l}\text { No. of } \\
\text { partici- } \\
\text { pants }\end{array}$ \\
\hline Management and Engineering & 56 \\
Electrical Engineering & 35 \\
Physics, Chemistry and Biology & 30 \\
Department of Computer and Information Science & 16 \\
Science and Technology & 13 \\
Medical and Health Sciences & 13 \\
Biomedical Engineering & 10 \\
Other & 15 \\
Total & 188 \\
\hline
\end{tabular}


a third based at the Department of Management and Engineering. The majority of the participants in the "other" group (comprising five departments) come from the Department of Clinical and Experimental Medicine, and the Centre for Medical Image Science and Visualization.

\subsection{Course content and process}

Like many other entrepreneurship courses, ETP is structured around workshops on various entrepreneurial topics and on new business development (Lackéus et al. 2015; Hägg 2017). For the most part, ETP has centred on entrepreneurship in various contexts and situations, opportunity recognition and development, team formation, new venture development, financing, marketing and sales of new and different ideas, intellectual property rights, entrepreneurial ecosystems, and case studies of successful as well as failed businesses. The course is conducted over a three-month period, comprises of 7.5 ECTC and is led by the chair in entrepreneurship at the university. A teaching team of eight persons with long practical experience in various forms of academic entrepreneurship is recruited for performing coaching and workshops in the course.

A central element in the course is the development of students' own ideas. Before the course begins, participants are asked to choose an idea they would like to develop during the course. Course leadership places no restrictions on content or orientation only that the idea should be linked with the research of the doctoral student. Ideas may be associated with a new spin-off firm, formulation of a new research project, or scientific methods for analysing research data. At the first meeting in the course, the participants present their ideas and the group then votes on the five to seven ideas that they think would be most interesting to focus on. The participants are then encouraged to form groups of two to three persons from different disciplines and organisational affiliations to draw up a development plan to realize one of ideas. Following a series of workshops and coaching sessions to aid in this activity, the groups present their ideas to a panel of experienced entrepreneurs in the academic system who give feedback, suggestions for network contacts, and other types of support. Since the ETP began, ninety ideas have been selected, developed, and presented and given the abundance of ideas from the students, it has sometimes been difficult to choose which ideas to focus on.

\subsection{Expected and unexpected results}

After the course, participants are expected to be able to (1) discuss and reflect on the meaning of entrepreneurship in various settings and situations; (2) formulate, develop, and present an idea for a new venture, organization, process, or project; (3) co-operate with colleagues in other disciplines and fields of research during idea development; and (4) understand how an entrepreneurial approach contributes to the development of the participant as a researcher and teacher. $\mathrm{PhD}$ students come from many research environments in science and technology, which has made it possible to discuss entrepreneurship issues from various angles. In fact, many of the doctoral students come from research environments where entrepreneurship and innovation are a natural part of their daily activities and senior researchers have much experience of commercialising research results. Course evaluations show that the $\mathrm{PhD}$ students appreciate the practical content of the course, the opportunity to collaborate across institutional boundaries, the new methodologies for solving problems, 
the possibilities to better understand how an entrepreneurial approach can contribute to each participant's academic career and how an entrepreneurial attitude can enhance future careers outside of the academic system.

These results are perhaps not so unexpected since they are similar to the course aims and learning objectives of the ETP. However, other more unexpected results emerged from the analysis of the participants' evaluation forms. For example, despite the importance of research within universities, there seemed to be little knowledge on issues over the commercialisation of this research by individuals, especially in relation to "the exemption for teachers" where Swedish law allows the researcher to retain the intellectual property rights to their research. "If I had known that, I would have acted in a completely other way" is a fairly usual comment from the evaluations of the ETP. Another observation is that the $\mathrm{PhD}$ students, through their participation, have come to represent a research group with an entrepreneurial mission to start new spin-off firms and as a result, the course has become a springboard into entrepreneurship and business for doctoral students. Since the programme began, over 20 new firms have been founded where a PhD student has played a central role in the founding team. What was also unexpected was the growth in the percentage of nonSwedish doctoral students participating in the course-from none at the beginning, they have become the largest participating group in the course and represent eleven different nationalities.

\section{Analysis and discussion}

The basis for the analysis is the aggregated responses from former ETP participants illustrated in the open-coding categories and sub-categories as well as the representative quotes shown in Table 2. A significant aspect to consider here is the predominant research context that may shape ETP participants' attitudes and perceived support towards third mission issues and academic entrepreneurship. Previous studies have shown that science and engineering doctoral students perceive their working environment as generally more supportive to academic entrepreneurship compared to their colleagues in arts, social and medical sciences (Bienkowska and Klofsten 2012). This is probably due to different traditions and practices regarding direction of mobility during the doctoral studies and that external collaborations in the technology-oriented research groups often enclose private firms. Moreover, many departments in the technical faculty have set a track record for turning sciencebased ideas into new technology ventures (Klofsten and Jones-Evans 1996; Rasmussen and Wright 2015). Development of new venture ideas is often part of the daily concerns among the research teams since starting up a firm can be a viable career alternative after completion of doctoral studies (Boh et al. 2016). This is evident in the analysis where the ETP participants tend to have high expectations and see the programme as being practically oriented, teaching the basics of starting a new venture and dealing with business-related issues.

Since the ETP course is not required for a PhD degree, support from supervisors and other colleagues in the research environment of the candidate is crucial for student's possibilities to participate in the programme. This supports the findings of other studies which report that the entrepreneurial behaviour of the individual depends a great deal on the local social norms of the group (Bercovitz and Feldman 2008; Bienkowska et al. 2016). Furthermore, the results show that inspiration is closely associated with interactions between different PhD candidates from other research environments and cultures, meeting 
Table 2 Open-coding categories and sub-categories with representative quotes

Categories Representative quotations

\section{Learning tools}

How to formulate, develop, and sell an idea to an audience

How to start and run a new venture

Understanding that entrepreneurship is something that can be learned

\section{Inspiration}

Meeting people from other countries and contexts inspires new ways of thinking

To be seen as an entrepreneur is a positive experience

Having the chance to meet entrepreneurial role models is inspiring and invigorating

Interdisciplinarity

Mixing individuals from different research disciplines contributes to a positive learning experience

When developing new ideas, teams with different theoretical backgrounds tend to experience synergy

Working on an interdisciplinary team is challenging: the outcome depends on clear respect for the ideas and opinions of the other team members

\section{Boundary spanning networks}

Relationships with $\mathrm{PhD}$ students from other parts of the university have persisted after the course

Relationships outside the academic context were built by involving external resource people in the course

Contacts made during the course have continued to be useful afterward
"I believe it is important to learn some theories and get some hands-on experience when developing new ideas even connected to my $\mathrm{PhD}$ theses"

"Helped me rethink about the skills needed to become an entrepreneur"

"I have always been interested in new ideas and startups-the course broadened my view here"

"I was curious and now I want to see if it is possible to start something on my own"

"I have always been fascinated by entrepreneurship, and now when I have meet a couple of them I have the dream to be an entrepreneur"

"The course was very encouraging! I can be an entrepreneurial researcher!"

"I met an Iranian guy from machine construction and we complement each other, able to make our vision come true"

"Meeting students outside physics is fantastic. They have completely different ways of seeing and doing things, related ideas, mind-set, motivation, knowledge..."

"It's good to know innovative ideas can come from every discipline, and different ways of thinking enrich the project. Communication is sometimes difficult but that is also a demanding —one needs to communicate clearly"

"I made friends in other divisions who were on the course, and later we took other courses together and shared knowledge, personal interests and hobbies"

"I still greet people from the course when I meet them on campus"

"It's fun to meet other types of researchers... outside the box, something I started thinking about when going to conferences"

entrepreneurial role models and being seen as an entrepreneur themselves. Earlier studies have shown that the entrepreneurial intentions of close peers and co-workers often serve as role models for others in order to take the steps to act entrepreneurially (Veciana, et al. 2005; Liñán and Fayolle 2015). In particular, this occurs among younger academics (such as doctoral students) who often join together with senior principal investigators on projects (Kenney and Goe 2004; Kirby 2006). What also occurs is that entrepreneurship can inspire $\mathrm{PhD}$ students to acquire new skills and take the step to develop new opportunities-ETP participation even enriches new ideas in the writing of the $\mathrm{PhD}$ thesis. 
One of the missions of ETP is to mix individuals of varying organizational and subject backgrounds using a concept that successfully yields positive learning and network building. ETP can therefore be considered a knowledge node where doctoral students with different nationalities, theoretical knowledge, and varying mind-sets meet and interact with each other. This results in a situation where the boundaries of the many different contexts have melted together through interdisciplinary collaborations to forge a new platform that is interdisciplinary in nature and which promotes the development of new ideas.

Several studies have shown the importance of boundary-spanning activities in stimulating the exchange between individuals and organizations to facilitate interdisciplinary knowledge sharing and technology transfer (Lamine et al. 2016). One of the aims of ETP has been to develop business capabilities in technology among academic faculties, startup ventures, industry clusters and other firms. ETP participants indicate that they have not only established relations with the other participants on the programme but also with internal and external lecturers who were involved in various phases of the course. In some cases, these relations have persisted long after the end of the course with some participants reporting the practical use of these contacts in their career.

The course itself has also assumed a boundary-spanning role through the skills development of the participants and a design that facilitates value-added knowledge exchange. New boundary-spanning roles such as liaison, scanning of market information, and mediation are evidence of the impact that the course has had on speeding up the transfer of knowledge within the framework of the course's projects on idea development. Boundary spanning individuals - in this case, $\mathrm{PhD}$ candidates with varying backgrounds and from different disciplines and organizations - can take on these new roles and share research developments and specialized information with each other that will aid in the commercialization of an idea (Zucker and Darby 1996; Youtie and Shapira 2008). In those cases where doctoral candidates choose not to continue in research but to undertake other roles in academia, private companies or government agencies, the skills they acquired in the course can be useful in boundary spanning and promoting interactions in scientific, technology-oriented business, public policy councils and company boards. Creating new tools and methods for sharing, involving actors on both sides of a boundary and developing new expertise in specific areas are interactions that have been highlighted by the triple-helix model as ways of fostering innovation and technology transfer (Elg et al. 2015; Etzkowitz and Zhou 2017).

\section{Conclusions and implications}

This study has shown how entrepreneurship education targeting doctoral science and technology students expands the understanding of entrepreneurship in a broad sense, with many outcomes that would not otherwise be likely (Gorman et al. 1997). The programme analysed by this paper reflects on a set of four key elements for entrepreneurship education-namely learning tools, inspiration, interdisciplinarity, and boundary spanning-and how these provide some of the essential ingredients for transforming entrepreneurship education practices into entrepreneurial learning. At the individual level, an entrepreneurship course strives to expand proactive behaviour skills that are important for success in various situations (Honig 2004). In future scientific roles, graduate students will be prepared to lead the creation of a new research field, management of a scientific project, or the establishment of a research centre. These scientific endeavours involve challenges similar 
to those faced by entrepreneurs with innovative ideas namely conceptualization, development, implementation and evaluation (Klofsten and Lundmark 2016) including being prepared to deal with risks, limited resources, time management, teamwork, communication, and conflict resolution (Kuratko 2005). At the institutional level, such an entrepreneurship course can function as an arena for bringing together students, faculty, staff, and the extramural community to solve problems in collaboration with firms and other stakeholders and for reinforcing the boundary spanning role of the university across different cultural and organisational boundaries (Youtie and Shapira 2008; Löfsten et al. 2020). As a result, the course has become a positive feedback mechanism for policy strategy at the university level in science, technology, and innovation. The study also indicates that the fine balance between theory and practice is a crucial selling point for recruiting science and technology students from across the university to an entrepreneurship programme and course designers of similar curricula should be aware that any content must reflect the skills that are applicable to "real-world" entrepreneurship (Klofsten et al. 2019). This requires an approach that is different to the one normally utilised in core doctoral courses as these students are not studying for a $\mathrm{PhD}$ in entrepreneurship. For example, adopting a hands-on experimental method as a pedagogical strategy where a learning-by-doing approach is used may be the ideal method as students can be organised into interdisciplinary groups where each participant brings varying skill sets to the table for solving the problem (Gibb 2002; Fayolle and Gailly 2008). The skills necessary for acquiring the theoretical knowledge needed in the project are usually universal within $\mathrm{PhD}$ candidates i.e. how to ask questions, how to search for answers in the literature, how to make contacts in their field. Therefore, courses such as ETP must focus on being practically oriented with students learning new entrepreneurship concepts through case studies and independent reading.

Finally, despite growth in numbers and influence, $\mathrm{PhD}$ students are often under-utilised within the university not only in entrepreneurship education but also for research commercialisation. Even though they are involved in a research group, the lives of $\mathrm{PhD}$ students can be very lonely, with most of their time dedicated to their own particular research problem (Wright and Lodwick 1989). The pressure to write papers and produce results in time for the thesis defence is stressful and these conditions are particularly challenging when universities are making efforts to become more entrepreneurial and interdisciplinary and their PhD students, whose research belongs on the cutting edge of knowledge, are isolated with no time for academic socialization. Thus, a graduate course in entrepreneurship could be one antidote for the traditional isolation of the doctoral researcher and the four key elements-learning tools for new ways to view a problem, inspiration as a reason to get involved, interdisciplinarity as an excuse to socialize, and boundary spanning because knowledge must cross borders to fertilize - could be an important way of supporting researchers as they undertake their PhDs (Lackéus et al. 2013; Kickul et al. 2011).

Acknowledgements Open access funding provided by Linköping University. We are grateful for the valuable comments from our anonymous reviewers that helped us to improve the paper.

Open Access This article is licensed under a Creative Commons Attribution 4.0 International License, which permits use, sharing, adaptation, distribution and reproduction in any medium or format, as long as you give appropriate credit to the original author(s) and the source, provide a link to the Creative Commons licence, and indicate if changes were made. The images or other third party material in this article are included in the article's Creative Commons licence, unless indicated otherwise in a credit line to the material. If material is not included in the article's Creative Commons licence and your intended use is not permitted by statutory regulation or exceeds the permitted use, you will need to obtain permission directly from the copyright holder. To view a copy of this licence, visit http://creativecommons.org/licenses/by/4.0/. 


\section{References}

Åkerlind, G., \& McAlpine, L. (2017). Supervising doctoral students: Variation in purpose and pedagogy. Studies in Higher Education, 42(9), 1686-1698.

Al-Dajani, H., \& Marlow, S. (2013). Empowerment and entrepreneurship: A theoretical framework. International Journal of Entrepreneurial Behaviour and Research, 19(5), 503-524.

Baum, J. R., \& Locke, E. A. (2004). The relationship of entrepreneurial traits, skill, and motivation to subsequent venture growth. Journal of Applied Psychology, 89(4), 587.

Bercovitz, J., \& Feldman, M. (2008). Academic entrepreneurs: Organizational change at the individual level. Organization Science, 19(1), 69-89.

Bienkowska, D., \& Klofsten, M. (2012). Creating entrepreneurial networks: Academic entrepreneurship, mobility and collaboration during PhD education. Higher Education, 64(2), 207-222.

Bienkowska, D., Klofsten, M., \& Rasmussen, E. (2016). PhD Students in the Entrepreneurial UniversityPerceived Support for Academic Entrepreneurship. European Journal of Education, 51(1), 56-72.

Boh, W. F., De-Haan, U., \& Strom, R. (2016). University technology transfer through entrepreneurship: Faculty and students in spinoffs. Journal of Technology Transfer, 41(4), 661-669.

Bonnet, H., Quist, J., Hoogwater, D., Spaans, J., \& Wehrmann, C. (2006). Teaching sustainable entrepreneurship to engineering students: The case of Delft University of Technology. European Journal of Engineering Education, 31(2), 155-167.

Brush, C. G., Duhaime, I. M., Gartner, W. B., Stewart, A., Katz, J. A., Hitt, M. A., et al. (2003). Doctoral education in the field of entrepreneurship. Journal of Management, 29(3), 309-331.

Corley, K. G., \& Gioia, D. A. (2004). Identity ambiguity and change in the wake of a corporate spin-off. Administrative Science Quarterly, 49(2), 173-208.

Davidsson, P., \& Klofsten, M. (2003). The business platform: Developing an instrument to gauge and to assist the development of young firms. Journal of Small Business Management, 41(1), 1-26.

Dubini, P., \& Aldrich, H. (1991). Personal and extended networks are central to the entrepreneurial process. Journal of Business Venturing, 6(5), 305-313.

Elg, M., Ellström, P. E., Klofsten, M., \& Tillmar, M. (2015). Sustainable development in organizations: Studies on innovative practices (pp. 1-15). Cheltenham: Edward Elgar.

Etzkowitz, H., \& Klofsten, M. (2005). The innovating region: Toward a theory of knowledge-based regional development. $R \& D$ Management, 35(3), 243-255.

Etzkowitz, H., \& Zhou, C. (2017). The Triple Helix: University-Industry-Government Innovation and Entrepreneurship. London: Routledge.

Fayolle, A., \& Gailly, B. (2008). From craft to science: Teaching models and learning processes in entrepreneurship education. Journal of European Industrial Training, 32(7), 569-593.

Fayolle, A., Gailly, B., \& Lassas-Clerc, N. (2006). Assessing the impact of entrepreneurship education programmes: A new methodology. Journal of European Industrial Training, 30(9), 701-720.

Gibb, A. (2002). In pursuit of a new 'enterprise' and 'entrepreneurship' paradigm for learning: Creative destruction, new values, new ways of doing things and new combinations of knowledge. International Journal of Management Reviews, 4(3), 233-269.

Gibb, A., \& Hannon, P. (2006). Towards the entrepreneurial university. International Journal of Entrepreneurship Education, 4(1), 73-110.

Glaser, B., \& Strauss, A. (1967). The discovery of grounded theory. Chicago: Adeline.

Gorman, G., Hanlon, D., \& King, W. (1997). Some research perspectives on entrepreneurship education, enterprise education and education for small business management: A ten-year literature review. International Small Business Journal, 15(3), 56-77.

Grimaldi, R., Kenney, M., Siegel, D. S., \& Wright, M. (2011). 30 years after Bayh-Dole: Reassessing academic entrepreneurship. Research Policy, 40(8), 1045-1057.

Guerrero, M., Urbano, D., Fayolle, A., Klofsten, M., \& Mian, S. (2016). Entrepreneurial universities: Emerging models in the new social and economic landscape. Small Business Economics, 47(3), 551-563.

Hägg, G. (2017). Experiential entrepreneurship education: Reflective thinking as a counterbalance to action for developing entrepreneurial knowledge, $\mathrm{PhD}$ dissertation, Sten K. Johnson Centre for Entrepreneurship, Lund University.

Hayter, C. S., \& Link, A. N. (2015). On the economic impact of university proof of concept centers. Journal of Technology Transfer, 40(1), 178-183.

Honig, B. (2004). Entrepreneurship education: Toward a model of contingency-based business planning. Academy of Management Learning and Education, 3(3), 258-273.

Honig, B., \& Karlsson, T. (2004). Institutional forces and the written business plan. Journal of Management, 30(1), 29-48. 
Huyghe, A., \& Knockaert, M. (2015). The influence of organizational culture and climate on entrepreneurial intentions among research scientists. Journal of Technology Transfer, 40(1), 138-160.

Kenney, M., \& Goe, W. R. (2004). The role of social embeddedness in professorial entrepreneurship: A comparison of electrical engineering and computer science at UC Berkeley and Stanford. Research Policy, 33(5), 691-707.

Kickul, J. R., Griffiths, M. D., Jayaram, J., \& Wagner, S. M. (2011). Operations management, entrepreneurship, and value creation: Emerging opportunities in a cross-disciplinary context. Editorial, Journal of Operations Management, 29, 78-85.

Kingon, A. I., Markham, S., Thomas, R., \& Debo, R. (2002). Teaching high-tech entrepreneurship: Does it differ from teaching entrepreneurship? (And does it matter?). In Proceedings of the American Society for engineering education annual conference and exposition, Albuquerque, NM: American Society for Engineering Education.

Kirby, D. A. (2006). Creating entrepreneurial universities in the UK: Applying entrepreneurship theory to practice. The Journal of Technology Transfer, 31(5), 599-603.

Klofsten, M., Fayolle, A., Guerrero, M., Mian, S., Urbano, D., \& Wright, M. (2019). The entrepreneurial university as driver for economic growth and social change-Key strategic challenges. Technological Forecasting and Social Change, 141, 149-158.

Klofsten, M., Heydebreck, P., \& Jones-Evans, D. (2010). Transferring good practice beyond organizational borders: Lessons from transferring an entrepreneurship programme. Regional Studies, 44(6), 791-799.

Klofsten, M., \& Jones-Evans, D. (1996). Stimulation of technology-based small firms-A case study of university-industry cooperation. Technovation, 16(4), 187-213.

Klofsten, M., \& Jones-Evans, D. (2000). Comparing academic entrepreneurship in Europe-The case of Sweden and Ireland. Small Business Economics, 14(4), 299-309.

Klofsten, M., \& Lundmark, E. (2016). Supporting new spin-off ventures-experiences from a university start-up program. In S. de Cleyn \& G. Festel (Eds.), Academic spin-offs and technology transfer in Europe: Best practices and breakthrough models (pp. 93-107). Cheltenham: Edward Elgar.

Kuratko, D. F. (2005). The emergence of entrepreneurship education: Development, trends, and challenges. Entrepreneurship Theory and Practice, 29(5), 577-598.

Lackéus, M., Lundqvist, M., \& Middleton, K. W. (2015). Opening up the black box of entrepreneurial education. In 3E Conference.

Lackéus, M., Lundqvist, M., \& Williams Middleton, K. (2013). How can entrepreneurship bridge between traditional and progressive education? In ECSB entrepreneurship education conference; Århus, Denmark; May 29-31.

Lamine, W., Mian, S., Fayolle, A., Wright, M., Klofsten, M., \& Etzkowitz, H. (2016). Technology business incubation mechanisms and sustainable regional development. Journal of Technology Transfer, $43,1121-1141$.

Liñán, F., \& Fayolle, A. (2015). A systematic literature review on entrepreneurial intentions: Citation, thematic analyses, and research agenda. International Entrepreneurship and Management Journal, 11(4), 907-933.

Löfsten, H., Klofsten, M., \& Cadorin, E. (2020). Science parks and talent attraction management: University students as a strategic resource for innovation and entrepreneurship. European Planning Studies. https ://doi.org/10.1080/09654313.2020.1722986.

Lyons, E., \& Zhang, L. (2018). Who does (not) benefit from entrepreneurship programs? Strategic Management Journal, 39(1), 85-112.

Neubauer, D. E., Mok, K. H., \& Jiang, J. (Eds.). (2017). The sustainability of higher education in an era of post-massification. London: Routledge.

Norrman, C., Bienkowska, D., Moberg, M., \& Frankelius, P. (2014). Innovative methods for entrepreneurship and leadership teaching in CDIO-based engineering education. In 10th International CDIO conference (pp. 15-19).

Osterwarder, A. (2010). Business model generation: A handbook for visionaries, game changers, and challengers. New York: Wiley.

Politis, D. (2005). The process of entrepreneurial learning: A conceptual framework. Entrepreneurship Theory and Practice, 29(4), 399-424.

Powell, E. E., \& Baker, T. (2017). In the beginning: Identity processes and organizing in multi-founder nascent ventures. Academy of Management Journal, 60(6), 2381-2414.

Rasmussen, E., \& Wright, M. (2015). How can universities facilitate academic spin-offs? An entrepreneurial competency perspective. Journal of Technology Transfer, 40(5), 782-799.

Sauermann, H., \& Roach, M. (2016). Why pursue the postdoc path? Science, 352(6286), 663-664. 
Shattock, M. (2000). Strategic management in European universities in an age of increasing institutional self-reliance. Tertiary Education and Management, 6(2), 93-104.

Singh, J. V., Tucker, D. J., \& House, R. J. (1986). Organizational legitimacy and the liability of newness. Administrative Science Quarterly, 31(2), 171-193.

Souitaris, V., Zerbinati, S., \& Al-Laham, A. (2007). Do entrepreneurship programmes raise entrepreneurial intention of science and engineering students? The effect of learning, inspiration and resources. Journal of Business Venturing, 22(4), 566-591.

Strauss, A., \& Corbin, J. (1998). Basics of qualitative research: Techniques and procedures for developing grounded theory (2nd ed.). Thousand Oaks, CA: Sage.

Svensson, P., Klofsten, M., \& Etzkowitz, H. (2012). An entrepreneurial university strategy for renewing a declining industrial city: The Norrköping way. European Planning Studies, 20(4), 505-525.

Swedish Agency for Growth Policy Analysis. (2015). Unga forskares karriärvägar: Meriteringsanställningar, jämställdhet, forskarmobilitet och forskningsfinansiering, official report, Myndigheten för tillväxtpolitiska utvärderingar och analyser, Östersund, Sweden.

Szulanski, G. (1996). Exploring internal stickiness: Impediments to the transfer of best practice within the firm. Strategic Management Journal, 17(S2), 27-43.

Thune, T. (2009). Doctoral students on the university-industry interface: A review of the literature. Higher Education, 58(5), 637.

Veciana, J. M., Aponte, M., \& Urbano, D. (2005). University students' attitudes towards entrepreneurship: A two countries comparison. The International Entrepreneurship and Management Journal, 1(2), $165-182$.

Wateridge, J. (1995). IT projects: A basis for success. International Journal of Project Management, 13(3), $169-172$.

Wright, J., \& Lodwick, R. (1989). The process of the PhD: A study of the first year of doctoral study. Research Papers in Education, 4(1), 22-56.

Yin, R. K. (2011). Applications of case study research. Beverly Hills: Sage.

Youtie, J., \& Shapira, P. (2008). Building an innovation hub: A case study of the transformation of university roles in regional technological and economic development. Research Policy, 37(8), 1188-1204.

Zucker, L. G., \& Darby, M. R. (1996). Star scientists and institutional transformation: Patterns of invention and innovation in the formation of the biotechnology industry. Proceedings of the National Academy of Sciences, 93(23), 12709-12716.

Publisher's Note Springer Nature remains neutral with regard to jurisdictional claims in published maps and institutional affiliations. 